\title{
ANALISIS KELAYAKAN ISI DAN BAHASA PADA BUKU TEKS SMA "BAHASA INDONESIA EKSPRESI DIRI DAN AKADEMIK" KELAS X SMA
}

\author{
OKTARINA PUSPITA WARDANI \\ Prodi PBSI, FKIP, Universitas Islam Sultan Agung \\ oktarinapw@unissula.ac.id
}

Pertama Diterima: 30 Juli 2017

Bukti Akhir Diterima: 10 Agustus 2017

\begin{abstract}
Abstrak
Unsur pendukung dalam pembelajaran salah satunya ialah buku teks. Kelayakan isi dan bahasa buku teks bahasa indonesia harus sesuai dengan kurikulum yang berlaku. Isi dari buku teks pembelajaran harus sesuai dengan kompetensi inti pada pembelajaran itu. Masalah dalam artikel ini ialah menganalisis kelayakan isis dan bahasa buku teks "Bahasa Indonesia Ekspresi Diri dan Akademik“. Metode penelitian menggunakan metode kualitatif. Instrumen yang digunakan berupa kartu kata untuk mengambil data dari buku teks "Bahasa Indonesia Ekspresi Diri dan Akademik" kelas X SMA. Data berupa kata, kalimat yang dideskripsikan. Hasil penelitian menunjukkan bahwa Analisis kelayakan isi buku teks pelajaran bahasa Indonesia ini sesuai dengan instrumen yang ditetapkan oleh BSNP, meliputi kesesuaian antara materi dan kurikulum dan kompetensi dasar yang berlaku, keakuratan materi yang ada di dalam buku, dan pendukung materi yang ada. Kelayakan bahasa meliputi komunikatif, dialogis dan interaktif, lugas, keruntutan alur pikir, koherensi, kesesuaian dengan kaidah bahasa Indonesia yang benar, dan penggunaan istilah dan simbol atau lambang yang sesuai dengan perkembangan peserta didik.
\end{abstract}

Kata kunci: kelayakan isi, kelayakan bahasa, Bahasa Indonesia

\begin{abstract}
Supporting elements in learning one of them is a textbook. The feasibility of the content and language of Indonesian textbooks should be in accordance with the applicable curriculum. The content of the learning textbook must be in line with the core competencies of the lesson. The problem in this article is to analyze the feasibility of isis and the language of the textbook "Indonesian Expression of Self and Academic". The research method used the qualitative method. The instrument used in the form of a word card to retrieve data from the textbook "Indonesian Expression of Self and Academic" class X SMA. Data are words, sentences that are described. The result of the research shows that the feasibility analysis of the textbook content of Indonesian language is in accordance with the instrument set by $B S N P$, covering the suitability between the material and the applicable curriculum and basic competence, the accuracy of the material contained in the book, and the supporting material available. Language eligibility includes communicative, dialogical and interactive, straightforward, mindset demands, coherence, conformity with the correct Indonesian language rules, and use of terms and symbols or symbols to suit the development of learners.
\end{abstract}


Keywords: content feasibility, language feasibility, Indonesian language

\section{PENDAHULUAN}

Buku teks merupakan salah satu unsur dalam menunjang sarana dan prasarana pendidikan serta mengacu pada tujuan pendidikan nasional. Buku teks pelajaran merupakan acuan wajib yang digunakan disekolah. Materi pembelajaran dalam buku teks memuat materi yang dapat meningkatkan keimanan dan ketakwaan, budi pekerti dan kepribadian, kemampuan penguasaan IPTEK, kepekaan dan kemampuan estetis, potensi fisik dan kesehatan.

Buku teks dikelompokkan menjadi dua, buku teks wajib dan buku teks penunjang. Buku teks wajib merupakan buku teks untuk pembelajaran di sekolah yang diterbitkan olek Departemen Pendidikan Nasional yang disusun oleh tim berkualitas serta memenuhi syarat kelayakan. Buku penunjang merupakan buku teks yang diterbitkan oleh penerbit swasta. Penulis buku teks penunjang dapat berupa tim atau mandiri sesuai pengalaman bidang tertentu.

Kelayakan buku teks satu dengan lainnya harrus sama. Buku teks yang diterbitkan oleh swasta harus sesuai dengan kriteria yang diberikan oleh pemerintah. Kualitas isi atau materi yang disampaikan harus sesuai dengan kurikulum. Bahasa yang digunakan dalam buku teks, penyajian buku teks harus pula disesuaikan dengan kurikulum yang berlaku (Kurikulum 2013).

Peraturan Menteri Pendidikan Nasional No. 11/2005 tentang Buku Teks Pelajaran, pasal 2 ayat (2) mengatakan bahwa "Selain buku teks pelajaran sebagaimana dimaksud pada ayat (1), guru menggunakan buku panduan pendidikan dan dapat menggunakan buku pengayaan, dan buku referensi untuk menunjang kegiatan pembelajarannya.

Buku teks pelajaran adalah buku acuan wajib yang digunakan di sekolah yang diharapkan mampu meningkatkan pengetahuan cabang ilmu tertentu dapat meningkatkan keimanan dan ketaqwaan, budi pekerti dan kepribadian, kemampuan penguasaan teknologi. Dengan ketersediaan buku teks tersebut peserta didik dituntut untuk rajin membaca seperti yang tercantum pada al- Quran surat Al- Alaq ayat 1

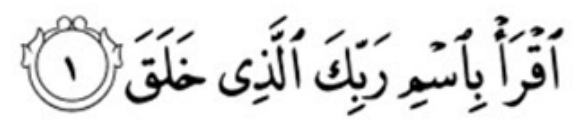


Bacalah dengan (menyebut) nama Tuhanmu yang Menciptakan (QS. Al-Alaq, ayat 1$)$.

Isi buku merupakan bahan pelajaran yang disajikan di dalam buku pelajaran. Untuk mengetahui isi di dalam buku pelajarandiperlukan ukura-ukuran standar yang mencangkup masalah a) kesesuaian materi dengan kurikulum, b) relevansi materi ditinjau dari segi tujuan pendidikan, c) kebenaran materi ditinjau dari segi ilmu bahasa dan ilmu sastra, dan d) kesesuaian materi pokok dengan tingkat perkembangan kognitif siswa.

Goodman dan Burk (Sumardi, 2000, hal 87) berpendapat bahwa untuk memilih dan mengembangkan bahan pelajaran bahasa perlu mempertimbangkan tiga hal, yaitu (1) kebutuhan siswa, (2) kedekatan bahasa dengan bahasa/kemampuan berbahasa siswa, dan (3) kemenarikan bahan tersebut bagi siswa. Bahasa pelajaran bahan yang baik yaitu ada kedekatan bahan bahasa tersebut dengan bahasa/kemampuan bahasa siswa. Hal ini perlu mendapat perhatian serius, mengingat karya buku adalah orang dewasa yang secara kematangan bahasa jauh lebih tinggi dari siswa. Sangat mungkin terjadi kesenjangan bahasa buku teks dengan kemampuan bahasa siswa.

Komponen kebahasaan ini diuraikan menjadi beberapa sub komponen atau indikator sebagai berikut. (1) Keterbacaan yaitu tingkatan bahasa yang bisa memahamkan pembaca dalam mempelajari buku teks tersebut; (2) Kesesuaian dengan kaidah bahasa Indonesia yang baik dan benar; (3) Logika berbahasa yaitu kesesuaian bahasa logika yang digunakan untuk memahamkan pembaca (Mulyono, 2007).

Berkenaan dengan pentingnya faktor buku pelajaran dalam pelaksanaan pembelajaran bahasa Indonesia di SMA, timbul pertanyaan mengenai standar buku SMA yang di pakai di sekolah saat ini baik di lihat dari segi penyajian isi dan bahasanya. Oleh karena itu, dilakukan penelitian mengenai buku teks SMA "Bahasa Indonesia Ekspresi Diri dan Akademik“" pembelajaran bahasa indonesia kurikulum 2013.

\section{METODE PENELITIAN}

Penelitian ini merupakan penelitian analisis isi, yaitu analisis yang bertujuan untuk mendeskripsikan data yang kompleks. analisis ini diungkapkan oleh Kripendorff (dalam Moleong 2007, hal 220) mengemukakan analisis isi adalah teknik penelitian 
yang dimanfaatkan untuk menarik simpulan yang replikatif dan sahih dari data atau dasar konteksnya.

Data pada penelitian ini ialah kata dan kalimat pada buku tek mengenai kajian isi (materi dan penyajian) dan kajian bahasa. Sumber data pada penelitian ini adalah buku teks SMA "Bahasa Indonesia Ekspresi Diri dan Akademik".Instrumen penelitian adalah kartu data yang dipergunakan untuk mencatat semua materi yang terdapat dalam buku ajar yang menjadi sumber data penelitian ini.

Teknik pengumpulan data yang digunakan dalam penelitian ini adalah teknik observasi dan teknik baca catat. Teknik analisis data pada penelitian ini menggunakan teknik analisis data secara deskriptif kualitatif. Deskrisi kualitatif digunakan untuk menganasis data dengan dengan membaca, memilah, dan mencatat.

\section{HASIL PENELITIAN DAN PEMBAHASAN}

\section{Kelayakan Isi pada Buku Teks SMA "Bahasa Indonesia Ekspresi Diri dan} Akademik“6

Ada tiga indikator yang harus diperhatikan dalam kelayakan isi buku teks, yaitu (1) kesesuaian uraian materi dengan kurikulum (KI dan KD) yang terdapat dalam kurikulum mata pelajaran yang bersangkutan; (2) keakuratan materi; dan (3) materi pendukung pembelajaran.

\section{Kesesuaian Uraian Materi dengan Kurikulum}

Buku teks bahasa Indonesia SMA/MA/SMK/MAK kurikulum 2013, belum sepenuhnya memenuhi kedalaman materi yang dibutuhkan siswa. Contoh pada materi pelajaran III tentang 'Budaya Berpendapat di Forum Ekonomi dan Politik' anak belum sepenuhnya faham dengan wacana tersebut walaupun terdapat gambar, ilustrasi tetapi, belum sepenuhnya mendapat kedalaman materi secara penuh.

\section{Keakuratan Materi}

Pemilihan wacana, teks, gambar, dan ilustrasi sesuai dengan kompetensi yang harus dicapai dan bermanfaat bagi pemenuhan rasa ingin tahu peserta didik Buku teks bahasa Indonesia SMA/MA/SMK/MAK kurikulum 2013, dari pelajaran I-VI pemilihan wacana, teks, gambar, dan ilustrasi pada kelas $\mathrm{X}$ ini sebagian besar sudah memenuhi kompetensi untuk peserta didik. Materi pada pelajaran III sub bab 'Budaya Berpendapat di Forum Ekonomi dan Politik' masih membingungkan sehingga wacana sulit untuk 
dipahami. Masih ada istilah pada materi yang belum memenuhi keakuratan. Sehingga, dapat menimbulkan kebingungan pada pembaca atau peserta didik.

Kesesuaian contoh dengan kompetensi yang ingin dicapai pada Buku teks Bahasa Indonesia, ekspresi diri dan akademik SMA/MA/SMK/MAK kelas X kurikulum 2013 sudah terpenuhi. Hal ini dapat dilihat dari contoh teks prosedur panduan menggunakan mesin ATM pada halaman 48, membuat KTP elektronik (hal 52), membuat SIM (hal 51) sudah dilemgkapi dengan contohnya. Dengan begitu, pembaca atau peserta didik dapat mempelajari beberapa hal baru melalui buku teks ini. Hal yang harus dipraktikkan dapat dipelajari melalui buku teks dengan cara dilengkapi dengan contoh.

Buku teks Bahasa Indonesia, ekspresi diri dan akademik SMA/MA/SMK/MAK kelas X kurikulum 2013 terdapat pelatihan, penugasan, dan terdapat penilaian sesuai dengan peruntutan penilaian auntentik. Contoh terdapat pelatihan disetiap akhir pelajaran (bab) dan terdapat pelatihan mandiri oleh peserta didik sehingga, bisa mengembangkan kecerdasan ketelitian peserta didik dan kurikulum 2013 mengedepankan kemandirian peserta didik sehingga peserta didik akan lebih aktif dan tanggap.

\section{Materi Pendukung Pembelajaran}

Buku teks Bahasa Indonesia, ekspresi diri dan akademik SMA/MA/SMK/MAK kelas X kurikulum 2013 terdapat pelatihan, penugasan, dan terdapat penilaian sesuai dengan peruntutan penilaian auntentik. Contoh terdapat pelatihan disetiap akhir pelajaran(bab) dan terdapat pelatihan mandiri oleh peserta didik sehingga, bisa mengembangkan kecerdasan ketelitian peserta didik dan kurikulum 2013 mengedepankan kemandirian peserta didik sehingga peserta didik akan lebih aktif dan tanggap.

Kelayakan Bahasa pada Buku Teks SMA "Bahasa Indonesia Ekspresi Diri dan Akademik6

Beberapa indikator yang harus diperhatikan kelayakan bahasa pada buku teks yakni 1) kesesuaian dengan tingkat perkembangan peserta didik, 2) komunikatif, 3) keruntutan dan kesatuan gagasan, 4) penyajian pembelajaran, 5) Kelengkapan Penyajian. 


\section{Kesesuaian dengan Tingkat Perkembangan Peserta Didik}

Bahasa Indonesia Ekspresi Diri dan Akademik SMA/MA/SMK/MAK kurikulum 2013, sudah memenuhi komponen tersebut. Bahasa Indonesia Ekspresi Diri dan Akademik SMA/MA/SMK/MAK kurikulum 2013, kesesuaian dengan tingkat perkembangan intelektual peserta didik sudah memenuhi di kurikulum 2013, karena pada perbab terdapat sistematika materi yang harus dipelajari secara mandiri, dan terdapat evaluasi berbahasa di bagian penutup buku teks kurikulum 2013.

Sudah memenuhi di buku teks tersebut. Karena peserta didik di kurikulum 2013 ini mengedepankan etika atau moral yang mandiri sehingga peserta didik dapat berkemang secara sosial dan emosional dalam setiap individu.

\section{Komunikatif}

Terdapat keterbacaan pesan pada kurikulum 2013. Tiap bab pada kurikulum 2013 terdapat keterbacaan pesan, dari pesan moral, hingga pesan yang harus disampaikan oleh peserta didik. Terdapat ketepatan bahasa pada kurikulum 2013. Ketepatan bahasa yang ada pada kurikulum 2013 sangat mudah dipahami oleh peserta didik sehingga peserta didik dapat belajar secara mandiri.

\section{Keruntutan dan Kesatuan Gagasan}

Bahasa Indonesia Ekspresi Diri dan Akademik SMA/MA/SMK/MAK kurikulum 2013 sudah memenuhi keruntutan dan keterpaduan bab. Pada buku teks kelas $\mathrm{X}$ terdapat ketentuan dan keruntutan bab yang mana dari bab I (hal 4) sampai bab VI (hal 149) isi dari perbab runtut dan dapat dipahami oleh peserta didik.

\section{Penyajian Pembelajaran}

Sudah memenuhi keterpusatan pendekatan saintifik dan model pembelajaran Discovery Learning dan Project Based Learning pada Bahasa Indonesia Ekspresi diri dan Akademik SMA/MA/SMK/MAK kelas X kurikulum 2013. Penyajian materi melalui wacana, teks, gambar, dan ilustrasi menempatkan peserta didik sebagai subjek pembelajaran sehingga uraian dalam buku mampu membentuk kemandirian belajar peserta didik, mengakomodasi belajar aktif berorientasi pendekatan saintifik dan model pembelajaran Discovery Learing, Project Based Learning, Problem Based Learning misalnya dengan tugas-tugas mandiri. Penyajian materi bersifat interaktif dan partisipatif yang memotivasi peserta didik terlibat secara mental dan emosional dalam 
pencapaian KI dan KD sehingga peserta didik termotivasi untuk belajar secara komprehensif tentang berbagai persoalan kebahasaan dan kesastraan.

Bahasa Indonesia Ekspresi diri dan Akademik SMA/MA/SMK/MAK kelas X kurikulum 2013, sudah memenuhi merangsang metakognisi peserta didik (sikap spiritual dan sikap sosial). Penyajian materi dapat mengembangkan motivasi belajar peserta didik dan merangsang peserta didik untuk berpikir kreatif tentang apa, mengapa, dan bagaimana mempelajari materi pelajaran dengan rasa senang dalam mengembangkan kompetensi sikap spiritual dan sikap sosial peserta didik.

Pada kurikulum 2013 peserta didik dituntut untuk belajar mandiri dan mengasah imajinasi, kreasi dan berpikir kritis. Penyajian materi dapat merangsang daya imajinasi dan kreasi berpikir peserta didik melalui ilustrasi, analisis kasus, dan latihan dalam mengembangkan kompetensi pengetahuan dan kompetensi keterampilan.

\section{Kelengkapan Penyajian}

Terdapat bagian pendahulu pada buku teks kurikulum 2013, a) Prakata: informasi yang mengantarkan pembaca untuk mengetahui tujuan penulis buku, ucapan terima kasih, dan harapan. (b) Daftar isi: daftar yang memuat informasi yang memudahkan peserta didik untuk mencari dan menemukan bab, subbab, serta topik yang ada di dalamnya pada buku teks kelas X kurikulum 2013.

Terdapat bagian isi pada buku teks kurikulum 2013. Bagian isi terdiri atas: (a) Pendahuluan: pengantar pada awal buku berisi tujuan penulisan buku teks pelajaran, sistematika buku, cara belajar yang harus diikuti, serta hal-hal lain yang dianggap penting bagi peserta didik. (b) Rujukan: wacana, teks, gambar, ilustrasi, tabel untuk pembentukan konteks dan pengembangan materi mempunyai identitas berupa judul, nomor urut gambar/tabel, dan rujukan. (c) Rangkuman dan refleksi: rangkuman merupakan konsep kunci bab yang bersangkutan yang dinyatakan dengan kalimat ringkas, jelas, dan memudahkan peserta didik memahami keseluruhan isi bab. Refleksi memuat simpulan sikap dan prilaku yang harus diteladani. (d) Pelatihan: latihan, kegiatan mandiri, dan penilaian untuk pencapaian kompetensi sesuai dengan KI dan KD. 


\section{PENUTUP}

Analisis kelayakan isi buku teks pelajaran bahasa Indonesia ini sesuai dengan instrumen yang ditetapkan oleh BSNP, meliputi kesesuaian antara materi dan kurikulum dan kompetensi dasar yang berlaku, keakuratan materi yang ada di dalam buku, dan pendukung materi yang ada. Kelayakan bahasa meliputi komunikatif, dialogis dan interaktif, lugas, keruntutan alur pikir, koherensi, kesesuaian dengan kaidah bahasa Indonesia yang benar, dan penggunaan istilah dan simbol atau lambang yang sesuai dengan perkembangan peserta didik.

\section{DAFTAR PUSTAKA}

Budiarti. (2009). Analisis Kualitas Materi Membaca Buku Teks Bahasa Jawa SMP Terbitan Aneka Ilmu. Skripsi: Unnes

Fathurrohman, Muhammad. (2012). Kategorisasi Nilai Religius . https://muhfathurrohman.wordpress.com

Kustanto, Hery dan A. Hinduan. (2009). Kecenderungan Buku Teks Fisika Lama dan Buku Teks Fisika Baru untuk SMA. Tesis. Yogyakarta: Program Pasca Sarjana Pendidikan Fisika UAD).

Moleong, Lexy J. (2002). Metodologi Penelitian Kualitatif. Bandung: Remaja Rosdakarya.

Mulyono, Pudji. (2007). Kegiatan Penilaian Buku Teks. Bulletin BSNP, 2 (1).

Muna. (2005). Kualitas Buku Pelajaran Bahasa dan Sastra Indonesia Kelas X SMA Terbitan Erlangga dan Grasindo. Skripsi: Unnes.

Muslich, Masnur. (2010). Text Book Writing. Jakarta: Ar-rus Media.

Priyanti. (2005). Kesesuaian dan Spiralisasi Pengembangan Materi Keterampilan Berbahasa pada Aspek Berbicara dalam Buku Teks Bahasa Indonesia.

Suherli. (2008). Buku Teks Layak Pakai di Sekolah. Online. Tersedia di http://suherlicentre.blogspot.com/2008/05/buku-teks-layak-pakai-disekolah.html.

Supriadi, Dedi. (2001). Anatomi Buku Sekolah di Indonesia. Yogyakarta: Adicita Karya Nusa. 